\title{
Precise Determination of Uranium Isotopes in Suez Canal Sediment
}

\author{
W. M. Abdellah \\ Radiation Protection Department, Nuclear and Radiological Regulatory Authority, Cairo, Egypt \\ Email:wmsra@yahoo.com
}

How to cite this paper: Abdellah, W.M. (2019) Precise Determination of Uranium Isotopes in Suez Canal Sediment. Journal of Analytical Sciences, Methods and Instrumentation, 9, 30-41. https://doi.org/10.4236/jasmi.2019.92004

Received: April 6, 2019

Accepted: June 2, 2019

Published: June 5, 2019

Copyright (c) 2019 by author(s) and Scientific Research Publishing Inc. This work is licensed under the Creative Commons Attribution International License (CC BY 4.0).

http://creativecommons.org/licenses/by/4.0/ (c) (i) Open Access

\begin{abstract}
The streambed sediments of the Suez Canal have been analyzed for determining the natural radionuclides and long-lived radionuclides such as uranium by gamma and alpha spectrometric techniques. The specific activities of ${ }^{238} \mathrm{U}$ series, ${ }^{232} \mathrm{Th}$ series and ${ }^{40} \mathrm{~K}(\mathrm{~Bq} / \mathrm{kg})$ were measured by gamma spectrometry based on Hyper-Pure Germanium detector (HPGe). The average specific activities of ${ }^{226} \mathrm{Ra}\left({ }^{238} \mathrm{U}\right)$ series, ${ }^{232} \mathrm{Th}$ series and ${ }^{40} \mathrm{~K}$ were ranged from $3.04 \pm$ 1.10 to $14.70 \pm 1.24 \mathrm{~Bq} / \mathrm{kg}$, from $1.12 \pm 0.66$ to $16.10 \pm 1.30$ and from $77 \pm$ 4.90 to $350.50 \pm 8.90 \mathrm{~Bq} / \mathrm{kg}$ respectively. The concentration of ${ }^{238} \mathrm{U}$ and ${ }^{234} \mathrm{U}$ in the streambed sediments are ranged from $3.24 \pm 0.21$ to $13.34 \pm 0.61 \mathrm{ppm}$ and from $3.18 \pm 0.02$ to $13.77 \pm 0.03 \mathrm{ppm}$ in dry weight respectively. ${ }^{234} \mathrm{U} /{ }^{238} \mathrm{U}$ ratios of the sediments are relatively lower than unity in many locations indicating the preferential uranium leaching process. The results with the high ratios for ${ }^{234} \mathrm{U} /{ }^{238} \mathrm{U}$ were observed in the sediment collected from Port Said. This may be attributed to the sorption of uranium by sediment which has a relatively high content of organic matter. The geochemical behavior of sediment, the chemistry of uranium and the flow rates of water are considered as the most important factors controlling uranium isotopic composition of the streambed sediment. The result of radioactivity in sediment samples can be used to distinguish any future changes due to non-nuclear industries on the Suez Canal area.
\end{abstract}

\section{Keywords}

Sediment, Uranium, Isotopic Ratios, Natural Radioactivity, Suez Canal, Egypt

\section{Introduction}

Suez Canal is the shortest international passage for marine shipping with mass transportation of petrochemicals, crude oil, and fertilizers or radioactive mate- 
rials. It passes through an area of considerable industrial, agricultural and tourist activities in which heavy metals may be released into the marine environment. The heaviest metals and radioactive isotopes have toxic effects on living organisms when exceeding a certain concentration [1] [2]. Transportation of radioactive materials is directly associated with the progress in every activity involving the use of nuclear energy, including education, medicine, industry, research, nuclear fuel cycle, and power generation. Increasing number and quantities of radioactive material in many different forms are being transported throughout the world which results in increased public concern about radiation safety in transport. There is a considerable amount of international trade transported in Egypt through the Suez Canal and this trade also involves the transportation of radioactive materials [3]. El-Tahawy et al. (1994) [4], measured the radioactivity levels of both natural and artificial radionuclides in the stream water of Suez Canal and related bottom sediments and found that the fate of released radionuclides would strongly depend on the chemical affinity to particulate matter in suspended loads and bottom sediments.

Over the past 20 years, much progress has been made in the understanding of the marine geochemistry of $U$, particularly regarding the pathways of removal from the ocean via precipitation in chemically reducing sediments. Pore-water depletion of $U$ and sediment enrichment of $U$ over detrital background levels by 1 to $10 \mu \mathrm{g} / \mathrm{g}$ have been observed in a number of anoxic basins [5] [6] [7].

$\gamma$-Spectrometry is a useful non-destructive method that permits the simultaneous determination of many radionuclides in a bulk sample, without the need for radiochemical separation. However, it is limited by the weak emission probabilities of many potentially useful emission lines, the poor efficiency of HPGe detectors over a wide energy range, the difficult task of precisely calibrating the efficiency of the detector, and the need to evaluate self-absorption and summation factors [8] [9].

$\alpha$-Spectrometry, with a detection limit often 100 - 1000 times lower than $\gamma$-spectrometry, is a very sensitive alternative technique. The efficiency of $\alpha$-particle detection depends only on geometric factors and, when a careful radiochemical separation process is carried out, it does not suffer from spectral interference. However, the overall process is time-consuming and impractical for large-scale screening of environmental samples. Thus, $\alpha$-spectrometry is used only for very specific aspects of environmental radioactivity surveys, in particular for uranium and plutonium determination [8] [9].

Diffusion of U (VI) from bottom water into sediments, followed by reduction to $\mathrm{U}$ (IV), which is precipitated or adsorbed to sediment solids, is regarded as the primary source of authigenic Uranium in these sediments. There is no doubt that authigenic Uranium formation in suboxic and anoxic sediments is the most important mechanism removing Uranium from ocean water, accounting for $40 \%$ to $70 \%$ of the riverine Uranium input flux [10] [11] [12]. Uranium concentrations and activity ratios have been studied in several environmental systems: ice-sheets (Koide and Goldberg, 1983) [13], soils (Greeman and Rose, 1990) 
[14], oceanic sediments (Barnes and Cochran, 1990) [15], groundwater (Copenhaver et al., 1992) [16], surface waters (Sarin et al., 1990) [17], etc. They have provided important information about the behavior of these radionuclides in the environment.

In this paper, the author describe a method, kept as simple as possible, for the determination of uranium content from sediment samples in addition to the comparison between the activity concentrations determined by gamma and alpha spectrometer.

The aim of the present work is the evaluation of the radiological baseline of the most important locations along the Suez Canal for the update and establishing the radiological map of that area. The work is extended to determine uranium concentrations and the isotopic ratios between ${ }^{234} \mathrm{U}$ and ${ }^{238} \mathrm{U}$ after radiochemical separation to clarify any potential variation of natural uranium in the sediment.

\section{Materials and Methods}

\subsection{Sample Collection}

Thirty marine sediment samples were collected from six mains locations along the canal, each sample about $1 \mathrm{~kg}$ was placed in a plastic bag and transported to the environmental laboratory. The collected samples were prepared for gamma counting by drying at $105^{\circ} \mathrm{C}$, crushed, homogenized and sieved through 200 mesh sieve shakers. A volume of $100 \mathrm{~cm}^{3}$ from the sample is transferred to a polyethylene container. The samples were collected from the heavy industrial locations on the long line of the Suez Canal starting from Athmanon coast (WA1) at the south of the canal followed by El-Ismailia port (WA2), El-Salam bridge (WA3), El-Qantara (WA4), Port Said (WA5) and Port Faud (WA6) in the north as depicted in Figure 1 [18]. The samples were sealed with silicon and stored for one month to ensure the secular equilibrium between parent and daughter isotopes in the nuclear chain, then measured by the Hyper Pure germanium detector (HPGe). The sediment samples from the locations under this investigation were analyzed by alpha spectrometry for the precise determination of uranium and the isotopic ratios between ${ }^{234} \mathrm{U}$ and ${ }^{238} \mathrm{U}$.

\subsection{Gamma Spectrometric Measurement}

The activity measurements have been performed by gamma ray spectrometer at Nuclear and Radiological Regulatory Authority using vertical HPGe detector of a relative efficiency about $40 \%$ and full width at half maximum (FWHM) of 1.95 $\mathrm{keV}$ for ${ }^{60} \mathrm{Co}$ gamma energy line at $1.33 \mathrm{MeV}$. The detector was operated with Canberra Genie 2000 software for gamma acquisition and analysis system supported by the LabSOCS (Laboratory Source less Calibration Software) [19]. The HPGe detector was contained in about $10 \mathrm{~cm}$ thickness free standing lead castle providing a low background environment, to shield the detector from lead fluorescent X-rays and bremsstrahlung. The lead was lined with $1.5 \mathrm{~mm}$ iron and 


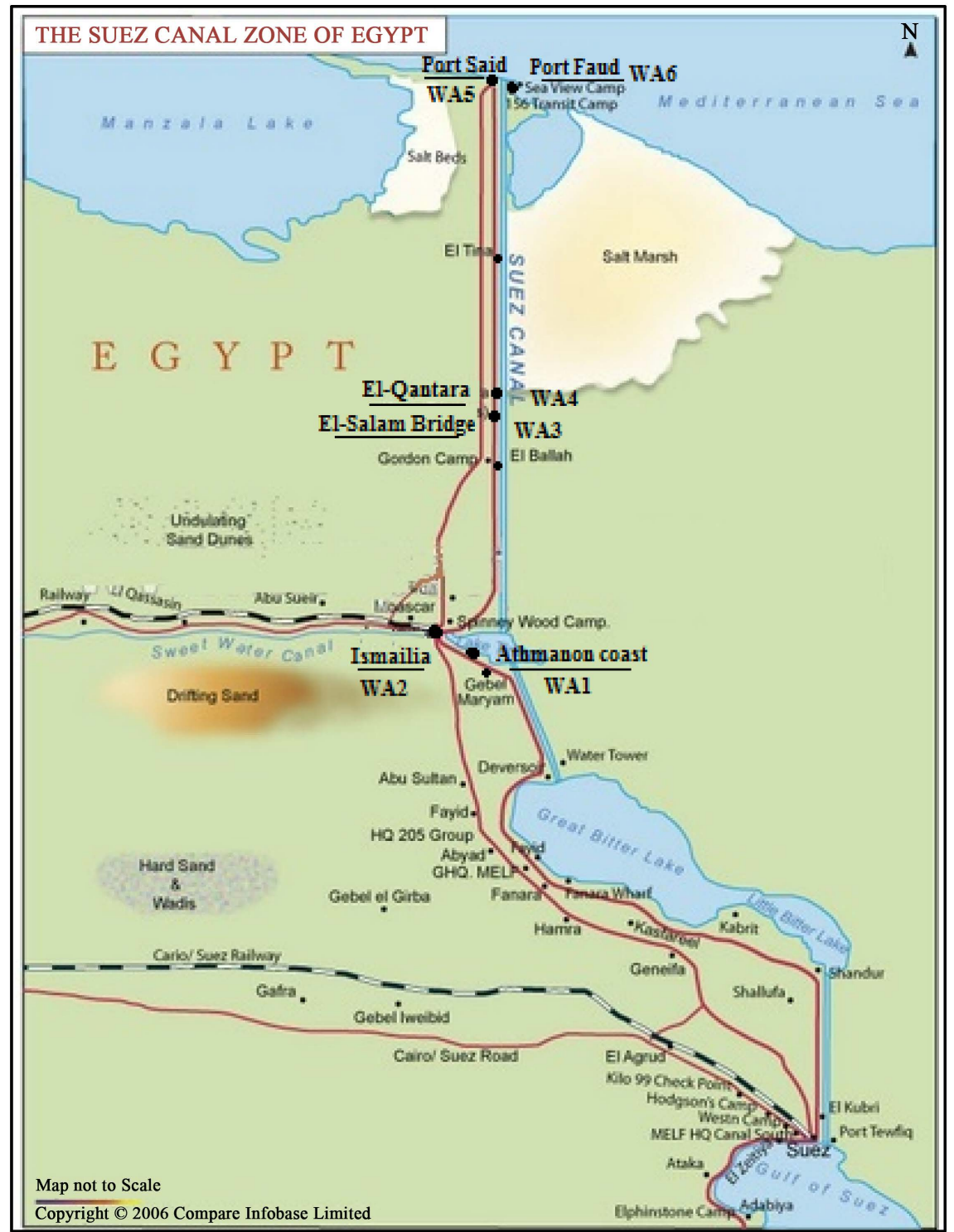

Figure 1. Sampling locations along the Suez Canal area [18].

$1.0 \mathrm{~mm} \mathrm{Cu}$ metals. Before performing the spectroscopic measurements, the spectrometer has been verified by using multi-nuclides standard sources distributed in the same geometry and a reference materials soil number (IAEA-326) which have certified concentration of natural radioactivity provided by the IAEA.

${ }^{238} \mathrm{U}$ cannot be measured directly from gamma ray spectrometry as it possesses only a feeble gamma line $49.55 \mathrm{keV}$ of very low emission probability $(0.064 \%)$. ${ }^{238} \mathrm{U}$ activity is usually estimated from gamma lines of radon daughters assuming secular equilibrium among its daughter radionuclides. This assumption holds good, only under undisturbed conditions, where there is a natural secular equilibrium between ${ }^{238} \mathrm{U}$ and ${ }^{226} \mathrm{Ra}$. Under oxidizing conditions, where uranium mostly stays in hexavalent states is more susceptible to leaching than radium. In such case, direct gamma line $63.29 \mathrm{keV}$ of ${ }^{234} \mathrm{Th}$, is the most suitable gamma energy to determine ${ }^{238} \mathrm{U}$ by gamma ray spectrometry [20]. However, thorium is 
highly insoluble of nature and therefore in case of disequilibrium between ${ }^{224} \mathrm{Ra}$ and thoron $\left({ }^{220} \mathrm{Rn}\right)$ daughters. Thorium concentrations cannot be measured from gamma lines of thoron daughters. In this case, two prominent gamma energies of ${ }^{228} \mathrm{Ac}$, the third member in the series, $338 \mathrm{keV}$ (11.3\%) and $911 \mathrm{keV}$ $(25.8 \%)$ are usually being used to estimate the parent thorium [21]. So, the specific activity calculations of ${ }^{238} \mathrm{U}$ and ${ }^{232} \mathrm{Th}$ series were obtained indirectly from the gamma rays emitted by their progenies assuming the secular equilibrium while ${ }^{40} \mathrm{~K}$ activities were determined from the $1460.7 \mathrm{keV}$ gamma line.

\subsection{Alpha Spectrometric Measurement}

1 gram from each sediment samples was ground until mesh size between 50 and 100 mesh, then digested by microwave model Mars CEM using $4 \mathrm{ml}$ conc. $\mathrm{HNO}_{3}$ and $4 \mathrm{ml} \mathrm{HCl}$ in the tube contained the sample and applying pressure $160 \mathrm{Psi}$ and temperature $190^{\circ} \mathrm{C}$. The samples took outside the instrument when the pressure reached $50 \mathrm{psi}$ and a temperature less than $50^{\circ} \mathrm{C}$. Finally, the samples treated with $4 \mathrm{ml}$ of HF to destroy the silica followed by evaporation to dryness for loss the excess of hydrofluoric acid. The residues were dissolved in $9 \mathrm{MHCl}$ followed by filtration and applying the radiochemical separation (Figure 2) that was studied and validated by the investigators Juhani (2001) [22] and Jukka et al. (2010) [23].

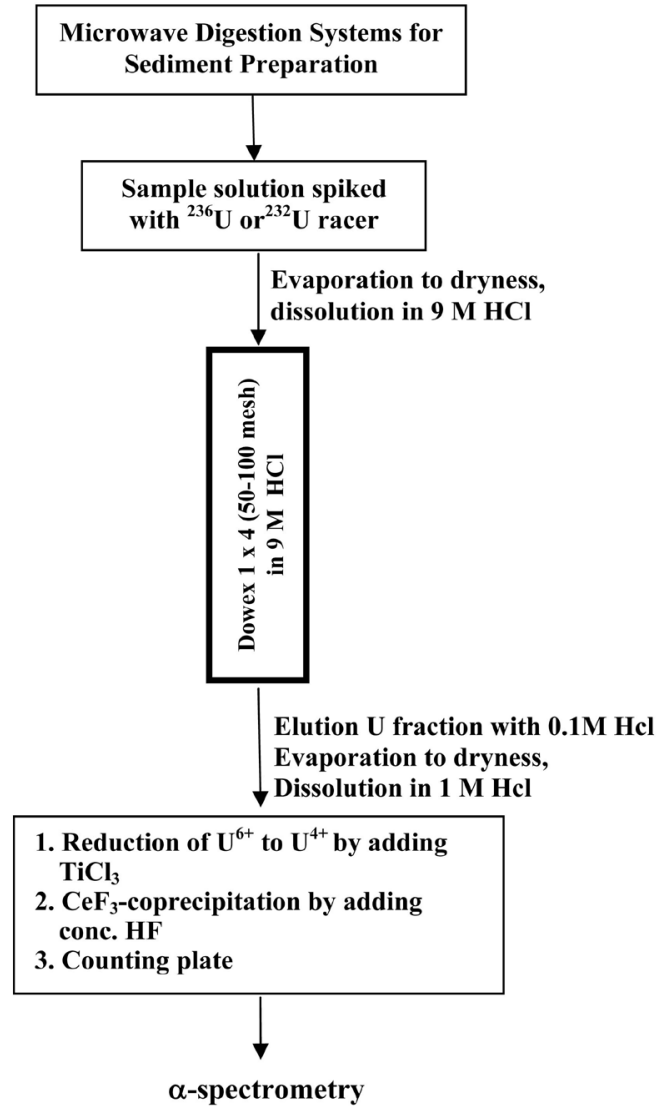

Figure 2. Schematic representation of the radiochemical separation of uranium. 
The activity concentration of uranium isotopes is determined according to the Equation (1):

$$
A_{\text {Nuclide }}=\frac{N_{\text {Nuclide }}-N_{\text {Background }}}{m \times t \times Y_{\text {Tracer }} \times e f f}
$$

Where: $N_{\text {Nuclide }}$ is the count from the studied nuclide, $N_{\text {Background }}$ is the background count, $t$ is the counting time (s), $m$ is the mass of the sample (kg) and eff is the efficiency of the detector (\%).

Quality assurance policies were followed for the methods by analyzing several environmental reference samples, e.g. IAEA-326, Dl-1a Canadian reference ore and blank samples. Alpha spectrometers, employing PIPS detectors with efficiencies ranged from $17 \%$ to $25 \%$ and an average resolution of $17 \mathrm{keV}$ in ${ }^{241} \mathrm{Am}$ alphas, and connected up to a computerized multi-channel analyzer operating with maestro software (ORTEC). The samples were measured for not less than $60,000 \mathrm{~s}$. The Minimum Detectable Activity (MDA), determined for the detection system and radiochemical procedures adopted in this study as presented by Equation (2) Currie, 1968 [24].

$$
\mathrm{MDA}=\frac{2.71+3.29 \sqrt{N_{p}}}{k * V * t}[\mathrm{~Bq} / \mathrm{cpm}]
$$

Where: $N_{p}$ is the background (CPM), $k$ is the calibration factor $(\mathrm{CPM} / \mathrm{Bq})$ and $m$ is the mass of the sample $(\mathrm{kg})$. The calibration factor was defined according to Equation (3)

$$
k=\frac{N}{t * A}
$$

Where: $t$ is the counting time of the sample (s), $A$ is the activity of the standard (Bq), and $N$ is the number of counts from the standard sample. The MDA was $0.17 \mathrm{mBq}$ for samples with counting time 1600 -minute and chemical recovery ranged between $75 \%-80 \%$.

\section{Results and Discussions}

The specific activity concentrations in the collected sediment samples for the radionuclides, ${ }^{226} \mathrm{Ra}\left({ }^{238} \mathrm{U}\right),{ }^{232} \mathrm{Th}$ series and ${ }^{40} \mathrm{~K}$ are determined by gamma spectrometry and presented in Table 1 . The obtained results showed that ${ }^{226} \mathrm{Ra}\left({ }^{238} \mathrm{U}\right)$ activities concentration ranged from $5.00 \pm 1.25$ to $13.91 \pm 1.18 \mathrm{~Bq} / \mathrm{kg}$ with an average of $8.34 \pm 1.44$ while ${ }^{232} \mathrm{Th}$ series from $2.5 \pm 0.90$ to $15.30 \pm 1.23$ with an average of $7.39 \pm 1.11$ and ${ }^{40} \mathrm{~K}$ from $90.70 \pm 6.30$ to $332.9 \pm 8.45$ with an average of $205.10 \pm 8.04 \mathrm{~Bq} / \mathrm{kg}$, these values are in agreement with the results obtained by other authors Waleed et al. in 2015 [25] and El Mamoney and Khater in 2004 [26].

The determined results for ${ }^{226} \mathrm{Ra}\left({ }^{238} \mathrm{U}\right),{ }^{232} \mathrm{Th}$ and ${ }^{40} \mathrm{~K}$ are lower than the international average for the radioactivity levels which are 35,50 and $500 \mathrm{~Bq} / \mathrm{kg}$ respectively as reported in UNSCEAR, 2000 [27]. The relatively high content of uranium series ${ }^{226} \mathrm{Ra}\left({ }^{238} \mathrm{U}\right)$ at Port Said (WA5) and Port Faud (WA6) locations 
Table 1. The average specific activity $(\mathrm{Bq} / \mathrm{kg})$ of ${ }^{226} \mathrm{Ra}\left({ }^{238} \mathrm{U}\right),{ }^{232} \mathrm{Th}$ and ${ }^{40} \mathrm{~K}$ in sediment samples using $\gamma$-Spectroscopy.

\begin{tabular}{cccc}
\hline $\begin{array}{c}\text { Sample } \\
\text { locations }\end{array}$ & $\begin{array}{c}{ }^{226} \mathrm{Ra}\left({ }^{238} \mathrm{U}\right) \\
(\mathrm{Bq} / \mathrm{kg})\end{array}$ & $\begin{array}{c}{ }^{232} \mathrm{Th} \\
(\mathrm{Bq} / \mathrm{kg})\end{array}$ & $\begin{array}{c}{ }^{40} \mathrm{~K} \\
(\mathrm{~Bq} / \mathrm{kg})\end{array}$ \\
\hline Athmanon Coast (WA1) & $5.00 \pm 1.25$ & $2.50 \pm 0.90$ & $95.77 \pm 5.10$ \\
Ismailia Port (WA2) & $6.11 \pm 1.20$ & $2.90 \pm 0.8$ & $290.60 \pm 8.90$ \\
El-Salam Bridge (WA3) & $5.50 \pm 1.23$ & $6.33 \pm 0.85$ & $89.67 \pm 6.10$ \\
El-Qantara (WA4) & $7.12 \pm 2.40$ & $4.50 \pm 1.02$ & $90.70 \pm 6.30$ \\
Port Said (WA5) & $13.05 \pm 1.40$ & $12.80 \pm 1.90$ & $330.90 \pm 13.70$ \\
Port Faud (WA6) & $13.91 \pm 1.18$ & $15.30 \pm 1.23$ & $332.97 \pm 8.45$ \\
Average & $8.45 \pm 1.44$ & $7.39 \pm 1.11$ & $205.10 \pm 8.09$ \\
\hline
\end{tabular}

may be attributed to the release of uranium through the wastewater contaminated with TE-NORM in the production of oil and gas industries. In addition, the high content of carbonate can increase the leaching of uranium with the formation of soluble carbonate complex. The geological nature in some locations may contain a reasonable content of uranium and that be easily leached to the water [25] [26] [27] [28]. In general, the average activity concentrations of $U$ in the area under this investigation are close to the reported values $20-50 \mathrm{~Bq} / \mathrm{kg}$ for uncontaminated sediments (UNSCEAR, 1988) [29].

The Radium equivalent $\left(R a_{e q}\right)$ has been calculated according to UNSCARE in 1994 [29], moreover the highest $R a_{e q}$ value reached $61.42 \pm 3.58 \mathrm{~Bq} / \mathrm{kg}$ in Port Faud (WA6) sediments, while the lower value amounted $15.95 \pm 2.93 \mathrm{~Bq} / \mathrm{kg}$ in Athmanon sediment (WA1). All the samples have radium equivalent lower than the limit set by the OECD (The Organization for Economic Cooperation and Development) report $\left(370 \mathrm{~Bq} / \mathrm{kg}\right.$ ) [30]. It is observed that $R a_{e q}$ values lower the maximum permissible radium activity (Ref. value is $370 \mathrm{~Bq} / \mathrm{kg}$ ) as reported by UNSCEAR, 1994 [31].

The Uranium results obtained by alpha spectrometry were summarized in Table 2, where the concentration of ${ }^{238} \mathrm{U}$ ranged from $3.24 \pm 0.21$ (WA4) to $13.34 \pm 0.61$ (WA5) ppm with an average $7.22 \pm 0.38 \mathrm{ppm}$ and for ${ }^{234} \mathrm{U}$ ranged from $3.18 \pm 0.02$ (WA4) to $13.77 \pm 0.34$ (WA5) ppm with an average $6.68 \pm 0.02$ ppm and chemical recovery about $80 \%$. The Conversion factors were used to convert $\mathrm{Bq} / \mathrm{kg}$ to ppm by the equations explained by IAEA in (2003) [32]. The results show that ${ }^{234} \mathrm{U}$ and ${ }^{238} \mathrm{U}$ are in radiological equilibrium, namely activity ratio of ${ }^{234} \mathrm{U}$ to ${ }^{238} \mathrm{U}$ being 1.0 [33], if the uranium was placed in a closed system. Isotopic fractionation of heavy elements such as uranium usually is less significant compared with that of light elements such as hydrogen and oxygen. It can be observed that the measured ${ }^{234} \mathrm{U} /{ }^{238} \mathrm{U}$ values are in good agreement with the (certified/reference) values [33]. The obtained result reflects the accuracy of radiochemical separation of uranium isotopes by alpha spectrometry as shown in Figure 3. 


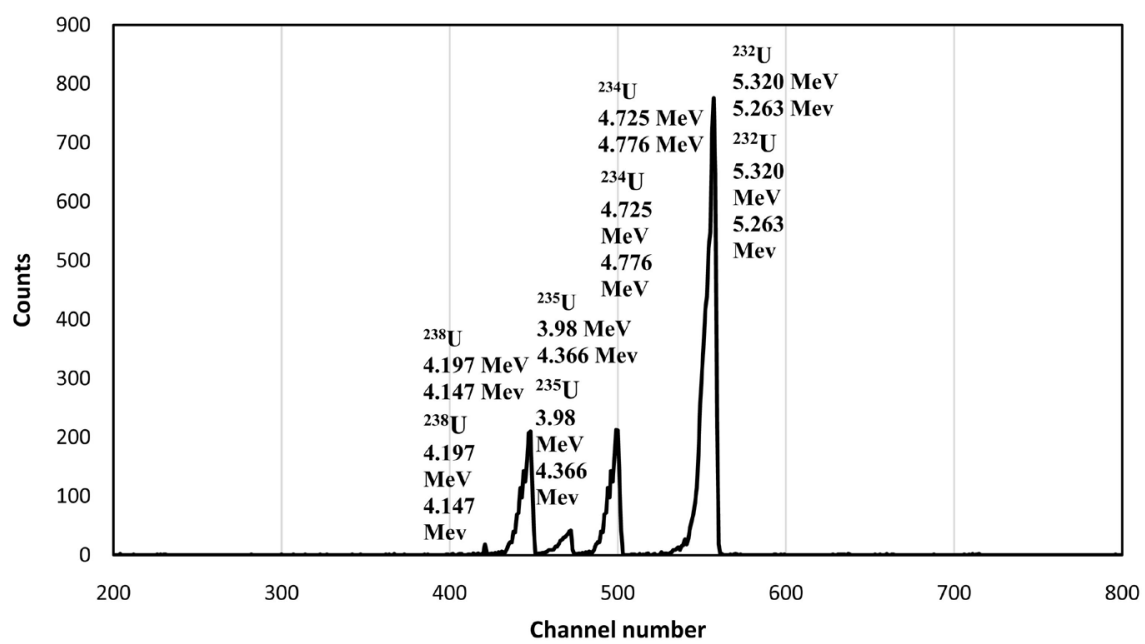

Figure 3. Spectrum result from Alpha spectrometry Using U-232 as a tracer for (WA5).

Table 2. Uranium concentration in ppm and the isotopic ratios between ${ }^{234} \mathrm{U}$ and ${ }^{238} \mathrm{U}$ from the studied locations.

\begin{tabular}{ccccccc}
\hline $\begin{array}{c}\text { Sample } \\
\text { locations }\end{array}$ & $\begin{array}{c}\text { Samples } \\
\text { code }\end{array}$ & $\begin{array}{c}{ }^{238} \mathrm{U} \\
\mathrm{ppm}\end{array}$ & $\begin{array}{c}{ }^{234} \mathrm{U} \\
\mathrm{ppm}\end{array}$ & $\begin{array}{c}{ }^{234} \mathrm{U} /{ }^{238} \mathrm{U} \\
\%\end{array}$ & $\begin{array}{c}{ }^{234} \mathrm{U} /{ }^{238} \mathrm{U} \\
\text { Ref. } \\
\text { value [33] }\end{array}$ & $\begin{array}{c}\text { Difference } \\
\text { (Ref.-Measured.) } \\
\%\end{array}$ \\
\hline $\begin{array}{c}\text { Athmanon Coast } \\
\text { Ismailia Port }\end{array}$ & WA1 & $6.51 \pm 0.35$ & $6.15 \pm 0.02$ & $0.95 \pm 0.06$ & 1.00 & 5 \\
El-Salam Bridge & WA3 & $4.82 \pm 0.26$ & $3.49 \pm 0.02$ & $0.91 \pm 0.06$ & 1.00 & 9 \\
El-Qantara & WA4 & $3.24 \pm 0.205$ & $3.18 \pm 0.02$ & $0.98 \pm 0.08$ & 1.00 & 2 \\
Port Said & WA5 & $13.34 \pm 0.61$ & $13.77 \pm 0.03$ & $1.03 \pm 0.06$ & 1.00 & -3 \\
Port Faud & WA6 & $10.59 \pm 0.59$ & $10.01 \pm 0.03$ & $0.95 \pm 0.06$ & 1.00 & 5 \\
\hline
\end{tabular}

The calculated isotopic ratios (Table 2) between ${ }^{234} \mathrm{U}$ and ${ }^{238} \mathrm{U}$ for all samples are relatively near unity and the redox regime may be expected for the corrosion of uranium isotopes from the sediment. The isotopic ratios below unity (0.9) indicating some degree of dissolution limited Uranium migration during the alternation of uranyl oxide hydrates was proposed on the basis of petrographic evidence and this may agree with Finch et al., in 1992 [34]. The most uranium concentration under the present work recorded their highest mean value (1.03) at North of the canal (Port Said) and this attributed to the locations at Port Said (WA5) and Port Faud (WA6) which are the most industrialized area in the north of Suez Canal. The difference between measured and reference value show a relatively small variation from -3 at (WA5) to 9 at locations (WA2 \& WA3).

The obtained results agreed with those studies by other investigators El-Moselhy et al. in 1998 [35] and Ibrahim N.M. in 1994 [36] who studied the pollution and uranium in the canal. The middle of the canal is affected mainly by agriculture effluents, shipyard of the Suez Canal and sewage discharge from Ismailia city. In Suez Canal, the principal process dominating the ecosystem is the mean sea level, the velocity and direction of the current which are responsible for the distribution of pollutants and radioisotopes such as uranium isotopes 
along Suez Canal [37].

These results can be interpreted as explained by another study [38] about the Uranium redox-sensitive and biologically-related element, and a small change to more reduced conditions that may be immobilize the soluble $\mathrm{U}(+6)$ to insoluble $\mathrm{U}(+4)$, while more oxidizing conditions have the reverse effect. Transfer of $U$ from water to sediments is known as arising from adsorption and/or adhesion onto settling particles including organic matter. An additional transfer of $U$ may result from diffusion into the sediments and reduction of $\mathrm{U}(+6)$ to $\mathrm{U}(+4)$ with precipitation of $\mathrm{U}(\mathrm{OH})_{4}$ at the redox boundary [38]. The most likely explanation of the relatively high ${ }^{234} \mathrm{U} /{ }^{238} \mathrm{U}$ activity ratio (larger than unity) in port Said WA5 is the preferential leaching of ${ }^{234} \mathrm{U}$ due to a recoil from rocks and sediments during weathering compared with ${ }^{238} \mathrm{U}$ from solid phase, caused by radiation damage of crystal lattice upon alpha decay of ${ }^{238} \mathrm{U}$ and oxidation of insoluble tetravalent ${ }^{234} \mathrm{U}$ to soluble hexavalent ${ }^{234} \mathrm{U}$ during decay solution phase [27] [37]. Comparison between uranium activity concentration in $\mathrm{Bq} / \mathrm{kg}$ dry weight, estimated by alpha and gamma spectroscopic measurements in the sediment samples show a wide variation from the equality ratios between ${ }^{238} \mathrm{U}$ and ${ }^{226} \mathrm{Ra}\left({ }^{238} \mathrm{U}\right)$ which may suggest a disturbance of equilibrium in sediment samples under the present study.

\section{Conclusion}

The activity concentration of uranium, thorium, and potassium in sediments from different locations along the Suez Canal has been determined. The mean activity concentration of ${ }^{226} \mathrm{Ra}\left({ }^{238} \mathrm{U}\right),{ }^{232} \mathrm{Th}$ and ${ }^{40} \mathrm{~K}$ were $8.45 \pm 1.44,7.39 \pm 1.11$ and $205.10 \pm 8.09 \mathrm{~Bq} \cdot \mathrm{kg}^{-1}$, respectively. The calculated Radium equivalent values were lower than the worldwide average reported by UNSCARE in 2000 [27]. The data indicated a wide deviation from the equality ratio, between ${ }^{238} \mathrm{U}$ determined by alpha and ${ }^{226} \mathrm{Ra}\left({ }^{238} \mathrm{U}\right)$ measured by gamma spectrometry which suggested a disturbance for the state of equilibrium in these sediments. Such disequilibrium may be attributed to escape of radon because its gaseous nature which leads to lowering all daughter isotopes in decay series, and hence lowering ${ }^{228} \mathrm{Ra}\left({ }^{238} \mathrm{U}\right)$ values. The selective deposition of ${ }^{226} \mathrm{Ra}$ and ${ }^{238} \mathrm{U}$ depend on the solubility product in water and the chemical composition. The activity ratio for ${ }^{234} \mathrm{U} /{ }^{238} \mathrm{U}$ is ranged from $0.91 \pm 0.06$ to $1.03 \pm 0.06$. The ${ }^{234} \mathrm{U} /{ }^{238} \mathrm{U}$ ratios were found to be relatively close to unity with a maximum difference $\sim 9 \%$ between the reference value and the certified value (1). The increase in the uranium concentration in the sediment has been indicated in Port Said (WA5) and Port Faud (WA6) as a result of the progressive and intensive increase of the industrial activities. Future work will explore the correlations between total dissolved uranium activity in the Canal water and chemical, physical characteristics of the Sediment.

\section{Acknowledgements}

The author very much appreciated the support provided by Helsinki University, Radiochemical Laboratory, Staff members, as well as the technical assistance 
from Dr. Juhani Suksi and Prof. Jukka Lehto.

\section{Conflicts of Interest}

The authors declare no conflicts of interest regarding the publication of this paper.

\section{References}

[1] Hassan, H.B. (2016) Effect of Suez Canal Marine Sediment on Sorption of Cesium. Journal of Nuclear Technology in Applied Science, 4, 113-121.

[2] Emara, M.M., Farid, N.A., El-Sabagh, E.A. and Ahmed, O.E. (2013) Physico-Chemical Study of Surface Seawater inThe Northwestern Gulf of Suez. Egyptian Journal of Chemistry, 56, 345-365. https://doi.org/10.21608/ejchem.2013.1117

[3] Sabek, G. (1987) Assessment of the Impact from Transporting Radioactive Materials in the Suez Canal. International Atomic Energy Agency, Report No. R-4292-F.

[4] El-Tahawy, M.S., Farouk, M.A., Ibrahiem, N.M. and El-Mongey, S.A.M. (1994) Natural and Artificial Radionuclides in the Suez Canal Bottom Sediments and Stream Water. Radiation Physics and Chemistry, 44, 87-89. https://doi.org/10.1016/0969-806X(94)90110-4

[5] Anderson, R.F. (1987) Redox Behaviors of Uranium in an Anoxic Marine Basin. Uranium, 3, 145-164.

[6] Huh, C.A., Zahnle, D.L., Small, L.F. and Noshkin, V.E. (1987) Budgets and Behaviors of Uranium and Thorium Series Isotopes in Santa Monica Basin Sediments. Geochimica et Cosmochimica Acta, 51, 1743-1754. https://doi.org/10.1016/0016-7037(87)90352-8

[7] Francois, R. (1988) A Study on the Regulation of the Concentrations of Some Trace Metals (Rb, Sr, Zn, Pb, Cu, V, Cr, Ni, Mn and Mo) in Saanich Inlet Sediments, British Columbia. Marine Geology, 83, 285-308.

https://doi.org/10.1016/0025-3227(88)90063-1

[8] Garcia-Talavera, M. (2003) Evaluation of the Sustainability of Various $\gamma$ Lines for the $\gamma$ Spectrometric Determination of ${ }^{238} \mathrm{U}$ in Environmental Samples. Applied Radiation and Isotopes, 59, 165-173. https://doi.org/10.1016/S0969-8043(03)00153-2

[9] Saidou Francois, B., Jean-Pascal, L., Kwato Njock, M.G. and Pascal, F. (2008) A Comparison of Alpha and Gamma Spectrometry for Environmental Natural Radioactivity Surveys. Applied Radiation and Isotopes, 66, 215-222. https://doi.org/10.1016/j.apradiso.2007.07.034

[10] Fleisher, M.Q., Anderson, R.F. and LeHuray, A.P. (1986) Uranium Deposition in Ocean Margin Sediments. Eos, Transactions, American Geophysical Union, AGU67, 1070

[11] Zheng, Y., Anderson, R., Geen, A. and Fleisher, M.Q. (2002) Remobilization of Authigenic Uranium in Marine Sediments by Bioturbation. Geochimica et Cosmochimica Acta, 66, 1759-1772. https://doi.org/10.1016/S0016-7037(01)00886-9

[12] Klinkhammer, G.P. and Palmer, M.R. (1991) Uranium in the Oceans: Where It Goes and Why. Geochim. Cosmochim. Geochimica et Cosmochimica Acta, 55, 1799-1806. https://doi.org/10.1016/0016-7037(91)90024-Y

[13] Koide, M. and Goldberg, E.D. (1983) Uranium Isotopes in the Greenland Ice-Sheet. Earth and Planetary Science Letters, 65, 245-248. https://doi.org/10.1016/0012-821X(83)90163-2 
[14] Greeman, D.J., Jester, W.A. and Rose, A.W. (1990) Form and Behavior of Radium, Uranium and Thorium in Central Pennsylvania Soils Derived from Dolomite. Geophysical Research Letters, 17, 833-836. https://doi.org/10.1029/GL017i006p00833

[15] Barnes, C.E. and Cochran, J.K. (1990) Uranium Removal in Oceanic Sediments and the Oceanic U balance. Earth and Planetary Science Letters, 97, 94-101. https://doi.org/10.1016/0012-821X(90)90101-3

[16] Copenhaver, S.A., Krishnaswami, S., Turekian, K.K. and Shaw, H. (1992) ${ }^{238} U$ and ${ }^{232}$ Th Series Nuclides in Ground Water from the J-13 Well at the Nevada Test Site; Implications for the Ion Retardation. Geophysical Research Letters, 19, 1383-1386. https://doi.org/10.1029/92GL01437

[17] Sarin, M.M., Krishnaswami, S., Somayajulu, B.L.K. and Moore, W.S. (1990) Chemistry of Uranium, Thorium, and Radium Isotopes in the Ganga-Brahmaputra River System: Weathering Processes and Fluxes to the Bay of Bengal. Geochimica et Cosmochimica Acta, 54, 1387-1396. https://doi.org/10.1016/0016-7037(90)90163-F

[18] The Suez Canal zone of Egypt (2017) Map of World Web. https://www.mapsofworld.com/egypt/suez-canal.html

[19] CANBERRA LabSOCS ${ }^{\mathrm{Tm}}$ Integration Services C49168-08/2016. http://www.canberra.com/services

[20] Lenka, P., Jha, S.K., Gothankar, S., Tripathi, RM. and Puranik, V.D. (2009) Suitable Gammaenergy for Gamma-Spectrometric Determination of ${ }^{238} \mathrm{U}$ in Surface Soilsamples of a High Rainfall Area in India. Journal of Environmental Radioactivity, 100, 509-514. https://doi.org/10.1016/j.jenvrad.2009.03.015

[21] Papachristodoulou, C.A., Assimakopoulos, P.A., Patronis, N.E. and Ioannides, K.G. (2003) Use of HPGe Gamma-Ray Spectrometry to Assessthe Isotopic Composition of Uranium in Soils. Journal of Environmental Radioactivity, 64, 195-203. https://doi.org/10.1016/S0265-931X(02)00049-8

[22] Juhani, S. (2001) Natural Uranium as a Tracer in Radionuclide Geosphere Transport Studies. Report Series in Radiochemistry, Helsinki University, Helsinki.

[23] Jukka, L. and Hou. X. (2010) Chemistry and Analysis of Radionuclides, Laboratory Techniques and Methodology. Wiley, [Hoboken, NJ, 69-71.

[24] Currie, L.A. (1968) Limits for Qualitative Detection and Quantitative Determination. Application to Radiochemistry. Journal of Analytical Chemistry, 40, 586-593. https://doi.org/10.1021/ac60259a007

[25] Waleed, M.A., Hanan, M.D., Ayman, M.E., Wesam, N.E. and Reda, M.A. (2015) Determination of Radioactivity Levels of Both Natural and Anthropogenic Radionuclides in Suez Canal. International Journal of Environmental Science, 4, 150-157.

[26] El Mamoney, M.H. and Khater, A.E.M. (2004) Environmental Characterization and Radioecological Impacts of Non-Nuclear Industries on the Red Sea Coast. Journal of Environmental Radioactivity, 73, 151-168. https://doi.org/10.1016/j.jenvrad.2003.08.008

[27] United Nations Scientific Committee on the Effects of Atomic Radiation, (UNSCEAR) (2000) Sources and Effects of Ionizing Radiation. Report to General Assembly, with Scientific Annexes, United Nation, New York.

[28] Lasheen, Y.F., EL-Zakla, T., Seliman, A.F. and Abdel-Rassoul, A.A. (2008) Direct Gamma-Ray Measurement of Differentradionuclides in the Surface Water of Suez Canal. Journal of Radiological Protection, 43, 255-272.

https://doi.org/10.1051/radiopro:2008002 
[29] United Nations Scientific Committee on the Effects of Atomic Radiation (UNSCEAR) (1988) Sources, Effects and Risks of Ionizing Radiation. UNSCEAR No. E88. IX.7, United Nations, New York.

[30] NEA-OECD (1978) Nuclear Energy Agency. Exposure to Radiation from Natural Radioactivity in Building Materials. Report by NEA Group of Experts, OECD, Paris.

[31] United Nations Scientific Committee on the Effects of Atomic Radiation (UNSCEAR) (1994) Exposure of the Population in the United State and Canada from Natural Background Radiation. NCRP Report No.94. National Council on Radiation Protection and Measurement, Bethesda, MD.

[32] International Atomic Energy Agency (2003) Guidelines for Radioelement Mapping Using Gamma Ray Spectrometry Data. TECDOC No.1363, Vienna.

[33] Lowson, R.T., Short, S.A., Davey, B.G. and Gray, D.J. (1998) ${ }^{234} U /{ }^{238} U$ and ${ }^{230} \mathrm{Th} /{ }^{234} \mathrm{U}$ Activity Ratios in Mineral Phases of a Lateritic Weathered Zone. Geochimica et Cosmochimica Acta, 50, 1697-1702. https://doi.org/10.1016/0016-7037(86)90131-6

[34] Finch, R.J. and Ewing, R.C. (1992) The Corrosion of Uraninite under Oxidizing Conditions. Journal of Nuclear Materials, 190, 133-156.

https://doi.org/10.1016/0022-3115(92)90083-W

[35] El-Moselhy, K.M., Hamed, M.A. and Abd El-Azim, H. (1998) Distribution of Mercury and Tin along the Suez Canal. Journal of the Egyptian-German Society of Zoology, 27, 33-42.

[36] Ibrahiem, N.M. and Pimpl, M. (1994) Uranium Concentrations in Sediments of the Suez Canal. Applied Radiation and Isotopes, 45, 919-921. https://doi.org/10.1016/0969-8043(94)90228-3

[37] El Samra, M.I., El Deeb, K.Z., Askar, A.I., Wahby, S.D. and El Shazly, M.S.H. (1983) Preliminary Study of Petroleum Hydrocarbon Pollution along the Suez Canal. Bulletin of the Institute of Oceanography and Fisheries, 9, 97-101.

[38] Din, K.S. and Vesterbacka, P. (2010) Spatial Distribution of U Isotopes in Sea-Water Sediments, Red Sea, Egypt. Journal of Environmental Radioactivity, 101, 165-169. https://doi.org/10.1016/j.jenvrad.2009.10.001 